УДК 343.575

12.00.00 Юридические науки

ДЕЯТЕЛЬНОСТЬ РУКОВОДИТЕЛЯ

СЛЕДСТВЕННОГО ОРГАНА, СВЯЗАННАЯ

С ФУНКЦИОНИРОВАНИЕМ ОПЕРАТИВНО-СЛЕДСТВЕННОЙ ГРУППЫ

Кучин Олег Стасьевич

доктор юридических наук, доцент, член-

корреспондент PAE, профессор кафедры

криминалистики

Московский государственный университет имени

М.В. Ломоносова, Москва, Россия

kuchin-os@rambler.ru

\begin{abstract}
Анализ положений УПК РФ и иных нормативноправовых актов, касающихся создания и функционирования следственной и оперативноследственной группы, показывает, что руководитель следственно-оперативной группы осуществляет, помимо прочих, организационноуправленческую функцию. Следовательно, его полномочия не ограничиваются одними лишь процессуальными функциями. В предлагаемой статье автор рассматривает, в чем заключаются эти функции и как они влияют на процедуру расследования преступлений

КЛючевые слова: СЛЕДСТВЕННЫЙ ОРГАН, ОПЕРАТИВНО-СЛЕДСТВЕННАЯ ГРУППА, СЛЕДОВАТЕЛЬ, ОПЕРАТИВНЫЙ СОТРУДНИК, РУКОВОДИТЕЛЬ СЛЕДСТВЕННОГО ОРГАНА, УГОЛОВНЫЙ ПРОЦЕСС, УГОЛОВНОЕ ДЕЛО, ПРЕСТУПЛЕНИЕ, КРИМИНАЛИСТИЧЕСКОЕ ОБЕСПЕЧЕНИЕ, ОПЕРАТИВНО-РОЗЫСКНАЯ ДЕЯТЕЛЬНОСТЬ
\end{abstract}

Doi: 10.21515/1990-4665-132-115
UDC 343.575

Legal sciences

\section{ACTIVITY OF THE HEAD OF \\ INVESTIGATION OFFICE IN REGARD WITH THE FUNCTIONING OF AN INVESTIGATION OPERATIONAL CROUP}

Kuchin Oleg Stasievich

Doctor of Law, Associate Professor, Corresponding

Member of RAN, Professor of Criminology

Moscow State University (MSU), Moscow, Russia

kuchin-os@rambler.ru
An analysis of the provisions of the Criminal Procedure Code and other regulatory legal acts relating to the investigation and operational investigation team activity shows that the head of the investigative and operational group exercises, among others, the organizational and managerial function. Consequently, these powers are not limited to procedural functions alone. In the proposed article, the author examines what these functions are and how they influence the procedure for investigating crimes

Keywords: INVESTIGATIVE BODY, INVESTIGATIVE GROUP, INVESTIGATOR, OPERATIONAL OFFICER, HEAD OF INVESTIGATIVE BODY, CRIMINAL TRIAL, CRIMINAL CASE, CRIME, FORENSIC SUPPORT, AND OPERATIVE-INVESTIGATIVE ACTIVITIES

Российский уголовный процесс не предусматривает легальной возможности создания в структуре правоохранительных органов оперативно - следственной группы для расследования конкретного уголовного дела. Вместе с тем, положения ст. 163 УПК РФ предусматривают возможность производства предварительного следствия следственной группой в случаях особой сложности, или большого объема по уголовному делу, что обычно и делается в основном при расследовании организованной преступной деятельности или особо тяжких преступлений. Вместе с тем указанная норма разрешает 
привлекать к работе следственной группы должностных лиц подразделений и органов, осуществляющих оперативно-розыскную деятельность. По мнению автора, совокупность данных норм как раз и подразумевает создание оперативно-следственной группы. В соответствии п. 1 ч. 1 ст. 39 и ч.2. ст. 163 УПК РФ руководитель следственного органа вправе принимать решение о производстве предварительного следствия следственной группой и об изменении ее состава.

Далее в ч. 2 ст. 163 УПК РФ изложено, что к работе следственной группы могут быть привлечены должностные лица органов, осуществляющих оперативно-розыскную деятельность. По смыслу и содержанию ст. 163 УПК РФ не совсем понятно, кто из должностных лиц, органа предварительного следствия вправе привлекать к работе следственной группы должностных лиц, осуществляющих оперативнорозыскную деятельность. Поскольку, в ст. 163 УПК РФ по этому поводу прямого указания не предписано, то возможно предположить, что данную деятельность может осуществлять как руководитель следственной группы, так и руководитель следственного органа.

По мнению автора в ст. 163 УПК РФ предусматривается организационно-управленческая деятельность руководителя следственного органа в принятии решения о создании следственной группы, в определении психологически совместимых, инициативных и опытных следователей, членов следственной группы, а также определении руководителя следственной группы. Более того, согласно п. 3 ч. 1 ст. 39 УПК РФ руководитель следственного органа вправе давать указания о направлении расследования, производстве отдельных следственных действий.

В соответствии с ч. 3 ст. 163 УПК РФ руководитель следственной группы организует работу следственной группы, руководит действиями других следователей, а согласно ч. 5 ст. 163 УПК РФ вправе участвовать в 
следственных действиях, проводимых другими следователями, лично проводит следственные действия и принимать решения по уголовному делу в порядке, установленном уголовно-процессуальным Кодексом Российской Федерации.

Анализируя нормы УПК РФ и нормативно-правовые акты, позволяющие осуществлять создание и функционирование не только следственной, но и оперативно-следственной группе, а также собственные предположения автора, позволили высказать мнение, о том, что руководитель следственно-оперативной группы осуществляет в том числе и организационно-управленческую деятельность. Следовательно, руководитель оперативно-следственной группы обладает не только процессуальными, а и определёнными организационно-управленческими полномочиями.

Поэтому, такая группа может быть организована на основе следственной группы, созданной решением руководителя следственного органа с привлечением к ней группы оперативных сотрудников, образованной начальником органа осуществляющего оперативнорозыскную деятельность, включенную в состав следственной группы совместным приказом руководителя следственного органа и начальника органа осуществляющего ОРД, об образовании оперативно-следственной группы. При этом следует иметь ввиду то, что деятельность оперативноследственной группы носит организационную форму сотрудничества руководителя следственной группы и руководителя оперативно-розыскной группы, основанной на четком разграничении обязанностей и ответственности.

Вопросам организации и взаимодействия органов предварительного следствия и подразделений органов осуществляющих ОРД преимущественно в системе полиции также посвящены работы многих 
известных криминалистов ${ }^{1}$. Специалисты в своих многочисленных исследованиях совершенно правильно указывали о неоспоримом приоритете оперативно-розыскных мероприятий в процессе выявления и документирования признаков преступления в уголовном преследовании².

Согласно ч.2 ст. 163 и п. 4 ч. 2 ст. 38 УПК РФ деятельность руководителя следственной группы или следователя следственной группы при взаимодействии с оперативным подразделением носит разовый характер и чаще всего осуществляется по очевидным преступлениям. Более того, по содержанию положения ст. 163 УПК РФ, руководителя следственной группы, и в контексте ст. 39 УПК РФ руководителя следственного органа, уголовно-процессуальный закон не наделяет полномочиями ходатайствовать о создании оперативной группы или оперативно-следственной группы для непосредственного взаимодействия со следственной группой по конкретному уголовному делу в процессе предварительного расследования.

Таким образом, уголовно-процессуальный закон наделяет руководителя следственной группы и следователя, члена следственной группы, правом только поручать разовые письменные поручения органу или должностному лицу, осуществляющему оперативно-розыскную деятельность.

\footnotetext{
${ }^{1}$ Еркенов С.Е. Взаимодействие правоохранительных органов стран СНГ при раскрытии и расследовании транснациональных преступлений : автореф. дис. ...д-ра. юр. наук. М., 2000. С. 29: Кучерук С.А. Тактика и взаимодействие органов следствия и дознания, как основа деятельности при раскрытии и расследовании преступлений в особо сложных условиях:автореф. дис. ...канд. юр. наук. Краснодар, 2002. С. 21-22.

${ }_{2}^{2}$ Горяинов К.К., Кваша Ю.Ф., Сурков К.В. Федеральный Закон «Об оперативнорозыскной деятельности» : комментарий. М.: Новый юрист, 1997; Оперативнорозыскная деятельность:учебник/ под ред. К.К. Горяинова, В.С. Овчинского, А.Ю. Шумилова. М.: Инфра-М: 2002; Основы оперативно-розыскной деятельности: учебник / под ред. В.Б. РушайлоСПб.: Изд-во Лань, 2002; Шахматов А.В. Агентурная работа в оперативно-розыскной деятельности: монография/ под ред. В.П. Сальникова. СПб.: Санкт-Петербургский университет МВД РФ, 2005.
} 
Анализ содержания положений норм уголовно-процессуального закона, регламентирующих образование и функционирование временно либо на постоянной основе действующих подразделений по расследованию преступлений группой следователей, позволяет высказать мнение об отсутствии в уголовно-процессуальном законе возможности создания оперативно-следственной группы, или придание оперативной группы непосредственно в подчинение к следственной группе. К таким группам относятся например: дежурная или специализированная оперативно-следственная бригада по расследованию неочевидных, тяжких и особо тяжких, серийных преступлений; постоянно действующей специализированной ОСГ по раскрытию и расследованию неочевидных преступлений прошлых лет и межгосударственная специализированная ОСГ по раскрытию и расследованию транснациональных преступлений; межведомственные специализированные ОСГ, когда интересы раскрытия и расследования преступления касаются нескольких министерств и ведомств, как правило это относится к сфере экономических преступлений. Вместе с тем, для возможного существования такой группы имеются соответствующие предпосылки в уголовно-процессуальном законе РФ. Так, производство расследования с использованием организационно-процессуального статуса руководителя следственной группы и следователя - это процессуальная деятельность; возможность привлечения к участию в организационно-процессуальной деятельности следователя и руководителя следственной группы по их письменным поручениям таких субъектов уголовного судопроизводства, как специалиста, оперативного сотрудника органа, осуществляющего оперативно-розыскную деятельность, а также различных сотрудников полиции, это также процессуальная и организационно-управленческая деятельность. Следовательно, такую уголовно-процессуальную 
деятельность возможно условно признать, как деятельность оперативноследственной группы, хотя, это в УПК РФ и не закреплено.

Вместе с тем, следует отметить, что условия и порядок формирования и функционирования оперативно-следственной группы по расследованию различных преступлений предписывают ведомственные нормативно-правовые акты ${ }^{3}$. Например, по представлению Министра внутренних дел Российской Федерации, согласованному с заинтересованными Федеральными органами исполнительной власти, Генеральной прокуратурой РФ и Следственным комитетом РФ, подписано Постановление Правительства России № 258 от 21 марта 2015 г. «О Порядке создания и деятельности совместных следственно-оперативных групп на территориях государств - участников содружества независимых государств», утвержденный распоряжением Президента России В.В. Путиным от 31 марта 2015 г. № 72-РП. Распоряжение Президента России дает возможность при подписании соглашения вносить в его проект изменения, не имеющие принципиального характера ${ }^{4}$.

Следственной практике известны случаи создания и функционирования постоянно действующих межведомственных групп ${ }^{5}$,

${ }^{3} \mathrm{O}$ некоторых вопросах организации оперативно-розыскной деятельности в системе МВД России:приказ МВД РФ от 15.08.2011 № 938; Организация создания и работы следственно-оперативной группы: приказ МВД РФ от 26.03.2008№ 280; Об утверждении инструкции по организации оперативно-служебной деятельности органов внутренних дел Российской Федерации при раскрытии преступлений и расследовании уголовных дел: приказ МВД РФ от 29.04.2015 № 495.

${ }^{4}$ В ч. 5 и 6 «Международного сотрудничества в сфере уголовного судопроизводства» в разделе 18 и 19 УПК РФ не предусмотрено создание следственно-оперативной группы. ${ }^{5}$ Об утверждении положення об организации межведомственного взаимодействия по противодействию переступлениям, совершаемым организованными группами и преступными сообществами (преступными организациями): совместный приказ Генпрокурора РФ № 192, МВД РФ № 420, ФСБ РФ № 279, СК РФ № 15, ФС РФ по контролю за оборотом наркотиков №229, ФТС РФ № 1071, ФСИН РФ № 293 от 14 мая 2013; О мерах по противодействию экстремистской деятельности: приказ СК РФ от 12.11.2011 № 109 и др. 
следственно-оперативных групп ${ }^{6}$ по отдельным видам или группам преступлений, или для раскрытия тяжких и особо тяжких преступленийㄱ, преступлений «старых, прошлых лет» создают также спецподразделения по раскрытию преступлений прошлых лет ${ }^{8}$.

В субъектах Российской Федерации также наблюдается правотворческая деятельность по совершенствованию взаимодействия правоохранительных органов. Например, постановление губернатора Еврейской Автономной области от 18.08.1998 № 182 «О создании межведомственной специализированной следственно-оперативной группы по борьбе с незаконным производством спирта и алкогольной продукции на территории ЕAO»; Постановление Главы администрации Краснодарского края от 03.12.1999 г. № 855 «О серьезных недостатках во взаимодействии правоохранительных органов, органов исполнительной власти и общественности в вопросах борьбы с организованной преступностью на территории Краснодарского края». Подобные постановления имеются и в других регионах страны 9.

${ }^{6}$ Инструкция об организации работы постоянно действующих следственнооперативных групп по раскрытию убийств: совместный приказ Генпрокурора РФ от 2 августа 1993 № 315-16-93 и МВД РФ от 2.08.1993 № 1/3452; Об утверждении Положения о совместных следственно-оперативных групп (бригадах) органов прокуратуры, внутренних дел, безопасности и налоговой полиции для пресечения и расследования деятельности организованных групп :совместный приказ Генпрокурора РФ № 32 МВД РФ № 199, ФСБ РФ № 73, ДНП РФ № 278 от 22.05.1995 и др.

${ }^{7}$ Об организации предварительного расследования в СК РФ от 15.01.2011 № 2.

${ }^{8}$ Об организации работы в следственном комитете РФ по раскрытию преступлений, совершаемых в прошлые годы:приказ СК РФ от 15.01.2011№ 10; Об использовании пенсионеров правоохранительных органов в качестве специалистов в системе МВД России: приказ МВД РФ от 29 марта 1993№ 137.

9 О взаимодействии медицинских организаций подведомственных Министерству здравоохранения Республики Бурятия, СУ СК РФ и МВД РФ по Республике Бурятия: совместный приказ Минздрава РБ № 4, СУ СК РФ и РБ № 41 и МВД РФ по РРБ № 845 от 15.12.2014; Об организации работы ответственных от руководства МВД, УВД ОВД и строевых подразделений МВД по контролю за полнотой и качеством проведения всего комплекса первоначальных следственно-оперативных и розыскных мероприятий в дежурные сутки, координации работы дежурных нарядов, сил и средств ОВД и подразделений МВД: приказ МВД Удмуртской Республики от 15.07.2008 № 462; О координационно-методическом совете по вопросам взаимодействия оперативных 
Анализ нормативно-правовых актов органов власти и управления позволяет уточнить классификацию оперативно-следственной группы следующим образом: по основанию субъекта, принимающему решение о создании следственно-оперативной группы (губернатора - главы администрации субъекта. Министры МВД и начальники ГУ МВД РФ субъектов России. Начальники отделов МВД РФ по городу, району, по собственной инициативе, либо по инициативе руководителя следственного органа, начальника полиции, а иногда прокурора). Например, по предложению министра внутренних дел России, Президентом и Премьерминистром РФ подписано соглашение о создании постоянно действующей следственно-оперативной группы стран СНГ для раскрытия и расследования преступлений; по правовой природе основанием принятия решения о создании следственной группы может быть по очевидным преступлениям, имеющим социальную значимость с выполнением большого объема или имеющих сложность для расследования уголовного дела. Создание следственной группы регламентируется ст. 163 УПК России, а следственно-оперативные группы создаются, как правило, на основании нормативно-правовых актов МВД России или СК РФ. В своей деятельности, оперативно-следственная группа руководствуется уголовнопроцессуальным законодательством. Оперативно-следственная группа создается, как правило, по неочевидным, тяжким или особо тяжким, многоэпизодным делам, имеющим определенную сложность и с выполнением большого объема работы по производству следственных и иных процессуальных действий и оперативно-розыскных мероприятий и в

подразделений: совместный приказ ГУ МВД РФ по Краснодарскому краю № 283 и УФСКН РФ по Краснодарскому краю № 168 от 28.02.2013; Об оперативно-розыскной группе МВД по КБР по выявлению и пресечению каналов и источников финансирования террористической и экстремистской деятельности: приказ МВД по Кабардино-Балкарской Республике от 6.09.2010 № 510; О постоянно действующих следственно-оперативных группах: совместный приказ Прокуратуры № 94, МВД № 34 и Минздрава Республики Башкортостана № 509-Д от 16.06.2002. 
целом по делу; по составу - в процессе деятельности следственной группы могут быть привлечены специалисты, переводчики к участию в следственных действиях, сотрудники, осуществляющие оперативнорозыскную деятельность, а также могут быть даны отдельные письменные поручения органу дознания для выполнения отдельных оперативнорозыскных мероприятий. В составе оперативно-следственных групп, как правило создается группа по управлению (штаб-планирование, контроль за исполнением плана, анализ материалов и определение стратегических и тактических направлений расследования, руководителем штаба является руководитель СОГ, а его заместителем - руководитель оперативнорозыскной группы).

В системе МВД РФ существует два вида следственно-оперативных групп: 1) дежурная следственно-оперативная группа назначается в составе суточного наряда по графику при дежурной части органа внутренних дел по приказу начальника полиции; 2) специализированная - для обеспечения четкого эффективного и оптимизированного взаимодействия подразделений ОВД в ходе расследования тяжких и особо тяжких преступлений или нераскрытых, неочевидных преступлений, в том числе и прошлых лет. Специализированная следственно-оперативная группа предназначена для расследования конкретного уголовного дела. Например, уголовные дела прошлых лет по однородным и отдельным видам, группам преступлений ${ }^{10}$.

10 Создание в МВД РФ и ГУ МВД РФ по некоторым субъектам России специализированные подразделения (следственно-оперативные группы) или совместные оперативные и рабочие группы в составе сотрудников управления уголовного розыска, СК РФ и Федеральной службы исполнения наказания (ФСИН). Участие сотрудников пенитенциарного ведомства в таких расследованиях обусловлено необходимостью получения информации от осужденных преступников. Новые подразделения уже добились первых результатов. Так, установлены и задержаны 16 участников банды, совершивших за 10 лет на территории Приморского края 18 убийств. Кроме того, задержаны восемь участников организованного преступного сообщества, действующего в Приволжском федеральном округе. Члены этой группировки совершили с 2002 по 2006 год 19 убийств, причем их жертвой стал лидер 
Специализированные следственно-оперативные группы также создаются по раскрытию и расследованию поджогов и пожаров, повлекших тяжкие и особо тяжкие последствия ${ }^{11}$. Следственнооперативные группы создаются также с участием следователей органов внутренних дел, следователей СК РФ, специалистов-криминалистов, следователей-криминалистов, экспертов судебно-экспертных учреждений, Федеральной противопожарной службы и экспертно-криминалистических подразделений системы МВД России, сотрудников уголовного розыска, по борьбе с экономической безопасностью и противодействию коррупции.

В зависимости от характера совершенного преступления, особенностей регионов в места их совершения, либо в условиях чрезвычайных обстоятельств, либо имеющих особую общественнополитическую значимость, или преступления транснационального характера создаются межведомственные или межгосударственные следственно-оперативные группы, или спецотделы в составе которого создаются: аналитическая группа, оперативно-розыскная группа, группа задержания, группа по производству следственных и иных процессуальных действий. Спецотделы, как правило, создаются в одном ведомстве, но с участием сотрудников других ведомств и министерств.

союза предпринимателей Мордовии Федор Катаев. Еще один пример раскрытого резонансного преступления - двойное убийство президента и исполнительного директора Московской областной нотариальной палаты Челышева и Петринского, совершенное в 2008 году. Всего за 11 месяцев 2010 г., было раскрыто 762 «старых» преступления. (См.: Информация на сайте: http: //-news/2011/01/14/3993123v_mvd_rf_vpervye_formiruyut_specpodra...12.06.2015).

${ }^{11}$ См.: Приказ МВД СССР от 30.04.1990 № 186; О создании следственно-оперативной группы МВД РФ для координации деятельности служб МВД и органов внутренних дел по раскрытию и расследованию пожаров и поджогов :приказ МВД РФ от 12.05.1993 № 224;Об организации взаимодействия органов ГПН ФПС ГПС РФ и органов внутренних дел РФ в использовании экспертно-криминалистических средств и методов в раскрытии и расследовании преступлений : совместный приказ Министерства РФ по делам гражданской обороны, чрезвычайным ситуациям и ликвидации стихийных бедствий № 549 и МВД РФ № 868 от 17 сентября 2012. 
Спецотделы свою деятельность осуществляют по реализации оперативно-розыскных материалов, полученных в ходе оперативнорозыскной деятельности по выявлению совершаемых или подготавливаемых тяжких и особо тяжких преступлений, имеющих особую общественную значимость, носящих межрегиональный, транснациональный характер ${ }^{12}$.

К сожалению, на практике по созданию следственных групп, особенно следственно-оперативной группы, дела обстоят не лучшим образом.

Указанные нормы регламентируют создание и функционирование следственных групп, в том числе с участием сотрудников органов, осуществляющих оперативно-розыскную деятельность, преследующих цель противодействия организованной преступности. За основу взят сравнительный метод исследования проблемы. Сопоставлены аналогичные действия должностных лиц по изучаемой проблеме до издания приказа за один год и после его издания до настоящего времени. На основе следственной группы и оперативно-розыскной группы совместным приказом начальника управления (отдела) внутренних дел МВД России и

12 Об утверждении Положения об оперативно-розыскной группе (спецотдела) МВД Кабардино-Балкарской Республики по выявлению и пресечению каналов и источников финансирования террористической и экстремисткой деятельности: приказ МВД по КБР от 06.09.2010 № 510; Инструкция по организации взаимодействия МВД РФ, Минобороны РФ, ФСБ, СВР и ФС по финансовому монитору по пресечению финансирования из зарубежных источников незаконных вооруженных формирований действующих в Северо-Кавказском регионе Российской Федерации: совместный приказ МВД, Минобороны, ФСБ, СВР и ФС по ФМ России от 14 мая 2007 № 426/183/117/43/106; Положение об организации межведомственного взаимодействия по противодействию преступлениям, совершаемым организованными группами и преступными сообществами (преступными организациями): совместный приказ Генпрокуратуры, МВД, ФСБ, СК, ФСКН, ФТС и ФСИН России от 14.05.2013 № 192/420/279/1071/293; Регламент информационного взаимодействия Банка России, Генпрокуратуры, правоохранительных и иных федеральных государственных органов РФ при выявлении и пресечении незаконных финансовых операций кредитных организаций и их клиентов: совместный приказ Генпрокуратуры, МВД, ФС по ФМ, ФНС, ФСБ, ФСКН, ФТС, СК и Центробанка Росси от 12 марта 2013 № 105/136/MМ-72/117/131/98/447/12/ОД-121. 
руководителя следственного органа по субъекту или административной территории субъекта создается единая структура оперативно-следственной группы с объявлением руководителя (руководитель СГ) и его заместителя (руководитель оперативно-розыскной группы).

Если в ГУ МВД России субъектов федерации одной из целей создания оперативной группы, исходя из содержания постановления описательно-мотивировочной части, ставилась задача по выявлению признаков организованности в деятельности преступных групп лиц, причастных к совершению расследуемого преступления, то в деятельности подразделений СУ СК РФ такая практика отсутствует.

При этом, несмотря на немногочисленные случаи создания оперативно-следственных групп по расследованию преступлений экономической направленности, имели место явно нерациональные способы использования сил и средств.

Большинство из оперативно-следственных групп не преследуют цели объединения усилий следователя и оперативного подразделения, в вопросах как уголовного преследования по конкретному уголовному делу, так и в целях противодействия преступности, в частности организованных еe форм.

Согласно ст. 163 УПК РФ в качестве руководителя следственной группы назначается, как правило, наиболее опытный следователь, старший следователь по особо важным делам, следователь-криминалист, заместитель руководителя следственного органа, имеющие наиболее выраженные организационно-управленческие способности. Следовательно, руководителем оперативно-следственной группы должен быть назначен следователь, у которого в производстве расследуемое уголовное дело. Естественно, за ним сохраняется руководящая роль, т.е. организует работу следственно-оперативных групп, руководит действиями других следователей и через руководителя оперативно-розыскной группы 
осуществляет планирование о проведении следственных и иных процессуальных действий, а также оперативно-розыскных мероприятий по делу, координирует совместное проведение следственных и иных процессуальных действий, определяет направление расследования и осуществляет его планирование совместно с членами ОСГ, распределяет работу между ними, координирует и контролирует их действия, знакомиться и оценивает материалы оперативно-розыскной деятельности и обеспечивает надлежащее использование материалов ОРД в расследовании в соответствии с инструкцией о порядке представления результатов ОРД органу дознания, следователю или в суд ${ }^{13}$.

На основании собранных материалов, в которых отражен весь комплекс криминалистически значимой информации, руководитель группы совместно с руководителем оперативно-розыскной группы, входящей в состав ОСГ, самостоятельно дают юридическую оценку информации, полученной в результате оперативного документирования преступной деятельности участников расследуемого преступления.

В необходимых случаях собранные оперативным сотрудником материалы, содержащие достаточные данные, указывающие на признаки преступлений, докладываются начальнику оперативного-розыскного подразделения, с согласия которого должностное лицо, осуществляющее оперативно-розыскную деятельность, составляет меморандум или в соответствии со ст.143 УПК РФ рапорт с признаками преступления, т.е. сведений о том, где, когда, какие признаки и какого именно преступления обнаружены, а также имеющиеся иные фактические данные по каждому установленному эпизоду противоправной деятельности; обстоятельств, при которых имело место по их обнаружению с информацией о времени, месте изъятия предметов, документов, материалов фотосъемки, аудио, видеозаписи (в

\footnotetext{
${ }^{13}$ См.: совместный приказ МВД Минобороны, ФСБ, ФСО, СВР, ФСИН, ФСКН, СК России от 27 сентября 2013 № 776/703/509/1820/42/535/398/68.
} 
том числе контроль и запись переговоров или получение информации о соединениях между абонентами и абонентскими устройствами, зафиксированными в ходе оперативно-розыскных мероприятий).

Получив информацию от руководителя следственного подразделения о наличии в материалах оперативно-розыскной деятельности, оснований для возбуждения уголовного дела либо, выполнив рекомендации о восполнении имеющихся в них пробелов, сотрудник оперативного подразделения подготавливает рапорт об обнаружении признаков преступления и регистрирует в Книге учета сообщений о происшествиях ${ }^{14}$ для рассмотрения вопроса о возбуждении уголовного дела ${ }^{15}$. После возбуждения уголовного дела составляется план расследования и план его оперативного сопровождения, а члены оперативно-следственной группы (следователи и оперативные сотрудники) приступают к его реализации и проведению полного и всестороннего расследования.

\section{Литература}

${ }^{11}$ Еркенов С.Е. Взаимодействие правоохранительных органов стран СНГ при раскрытии и расследовании транснациональных преступлений : автореф. дис. ...д-ра. юр. наук. М., 2000. С. 29: Кучерук С.А. Тактика и взаимодействие органов следствия и дознания, как основа деятельности при раскрытии и расследовании преступлений в особо сложных условиях:автореф. дис. ...канд. юр. наук. Краснодар, 2002. С. 21-22.

${ }^{[2]}$ Горяинов К.К., Кваша Ю.Ф., Сурков К.В. Федеральный Закон «Об оперативнорозыскной деятельности» : комментарий. М.: Новый юрист, 1997; Оперативнорозыскная деятельность:учебник/ под ред. К.К. Горяинова, В.С. Овчинского, А.Ю. Шумилова. М.: Инфра-М: 2002; Основы оперативно-розыскной деятельности: учебник / под ред. В.Б. РушайлоСПб.: Изд-во Лань, 2002; Шахматов А.В. Агентурная работа в

14 Об утверждении Инструкции о порядке приема, регистрации и разрешения в территориальных органах Министерства внутренних дел Российской Федерации заявлений и сообщений о преступлениях, об административных правонарушениях, о происшествиях : приказ МВД России от 29 августа 2014 № 736.

15 Об утверждении Инструкции о порядке представления результатов оперативнорозыскной деятельности органу дознания, следователю или в суд : приказ МВД России, Минобороны России, ФСБ России, ФСО России, ФТС России, СВР России, ФСИН России, ФСКН России, Следственного Комитета Российской Федерации от 27 сентября 2013 №776/703/509/507/1820/42/535/398/68. 
оперативно-розыскной деятельности: монография/ под ред. В.П. Сальникова. СПб.: Санкт-Петербургский университет МВД РФ, 2005.

${ }^{[3]} \mathrm{O}$ некоторых вопросах организации оперативно-розыскной деятельности в системе МВД России:приказ МВД РФ от 15.08.2011 № 938; Организация создания и работы следственно-оперативной группы: приказ МВД РФ от 26.03.2008№ 280; Об утверждении инструкции по организации оперативно-служебной деятельности органов внутренних дел Российской Федерации при раскрытии преступлений и расследовании уголовных дел: приказ МВД РФ от 29.04.2015 № 495.

${ }^{[4]}$ В ч. 5 и 6 «Международного сотрудничества в сфере уголовного судопроизводства» в разделе 18 и 19 УПК РФ не предусмотрено создание следственнооперативной группы.

${ }^{[5]}$ Об утверждении положення об организации межведомственного взаимодействия по противодействию переступлениям, совершаемым организованными группами и преступными сообществами (преступными организациями): совместный приказ Генпрокурора РФ № 192, МВД РФ № 420, ФСБ РФ № 279, СК РФ № 15, ФС РФ по контролю за оборотом наркотиков №229, ФТС РФ № 1071, ФСИН РФ № 293 от 14 мая 2013; О мерах по противодействию экстремистской деятельности: приказ СК РФ от 12.11.2011 № 109 и др.

${ }^{[6]}$ Инструкция об организации работы постоянно действующих следственнооперативных групп по раскрытию убийств: совместный приказ Генпрокурора РФ от 2 августа 1993 № 315-16-93 и МВД РФ от 2.08.1993 № 1/3452; Об утверждении Положения о совместных следственно-оперативных групп (бригадах) органов прокуратуры, внутренних дел, безопасности и налоговой полиции для пресечения и расследования деятельности организованных групп :совместный приказ Генпрокурора РФ № 32 МВД РФ № 199, ФСБ РФ № 73, ДНП РФ № 278 от 22.05.1995 и др.

[7] Об организации предварительного расследования в СК РФ от 15.01.2011 № 2.

${ }^{[8]}$ Об организации работы в следственном комитете РФ по раскрытию преступлений, совершаемых в прошлые годы:приказ СК РФ от 15.01.2011№ 10; Об использовании пенсионеров правоохранительных органов в качестве специалистов в системе МВД России: приказ МВД РФ от 29 марта 1993№ 137.

${ }^{[9]}$ О взаимодействии медицинских организаций подведомственных Министерству здравоохранения Республики Бурятия, СУ СК РФ и МВД РФ по Республике Бурятия: совместный приказ Минздрава РБ № 4, СУ СК РФ и РБ № 41 и МВД РФ по РРБ № 845 от 15.12.2014; Об организации работы ответственных от руководства МВД, УВД ОВД и строевых подразделений МВД по контролю за полнотой и качеством проведения всего комплекса первоначальных следственно-оперативных и розыскных мероприятий в дежурные сутки, координации работы дежурных нарядов, сил и средств ОВД и подразделений МВД: приказ МВД Удмуртской Республики от 15.07.2008 № 462; О координационно-методическом совете по вопросам взаимодействия оперативных подразделений: совместный приказ ГУ МВД РФ по Краснодарскому краю № 283 и УФСКН РФ по Краснодарскому краю № 168 от 28.02.2013; Об оперативно-розыскной группе МВД по КБР по выявлению и пресечению каналов и источников финансирования террористической и экстремистской деятельности: приказ МВД по Кабардино-Балкарской Республике от 6.09.2010 № 510; О постоянно действующих следственно-оперативных группах: совместный приказ Прокуратуры № 94, МВД № 34 и Минздрава Республики Башкортостана № 509-Д от 16.06.2002.

${ }^{[10]}$ Создание в МВД РФ и ГУ МВД РФ по некоторым субъектам России специализированные подразделения (следственно-оперативные группы) или совместные оперативные и рабочие группы в составе сотрудников управления уголовного розыска, СК РФ и Федеральной службы исполнения наказания (ФСИН). 
Участие сотрудников пенитенциарного ведомства в таких расследованиях обусловлено необходимостью получения информации от осужденных преступников. Новые подразделения уже добились первых результатов. Так, установлены и задержаны 16 участников банды, совершивших за 10 лет на территории Приморского края 18 убийств. Кроме того, задержаны восемь участников организованного преступного сообщества, действующего в Приволжском федеральном округе. Члены этой группировки совершили с 2002 по 2006 год 19 убийств, причем их жертвой стал лидер союза предпринимателей Мордовии Федор Катаев. Еще один пример раскрытого резонансного преступления - двойное убийство президента и исполнительного директора Московской областной нотариальной палаты Челышева и Петринского, совершенное в 2008 году. Всего за 11 месяцев 2010 г., было раскрыто 762 «старых» преступления. (См.: Информация на сайте: http: //-news/2011/01/14/3993123v_mvd_rf_vpervye_formiruyut_specpodra...12.06.2015).

${ }^{[11]}$ См.: Приказ МВД СССР от 30.04.1990 № 186; О создании следственнооперативной группы МВД РФ для координации деятельности служб МВД и органов внутренних дел по раскрытию и расследованию пожаров и поджогов :приказ МВД РФ от 12.05.1993 № 224;Об организации взаимодействия органов ГПН ФПС ГПС РФ и органов внутренних дел РФ в использовании экспертно-криминалистических средств и методов в раскрытии и расследовании преступлений : совместный приказ Министерства РФ по делам гражданской обороны, чрезвычайным ситуациям и ликвидации стихийных бедствий № 549 и МВД РФ № 868 от 17 сентября 2012.

${ }^{[12]}$ Об утверждении Положения об оперативно-розыскной группе (спецотдела) МВД Кабардино-Балкарской Республики по выявлению и пресечению каналов и источников финансирования террористической и экстремисткой деятельности: приказ МВД по КБР от 06.09.2010 № 510; Инструкция по организации взаимодействия МВД РФ, Минобороны РФ, ФСБ, СВР и ФС по финансовому монитору по пресечению финансирования из зарубежных источников незаконных вооруженных формирований действующих в Северо-Кавказском регионе Российской Федерации: совместный приказ МВД, Минобороны, ФСБ, СВР и ФС по ФМ России от 14 мая 2007 № 426/183/117/43/106; Положение об организации межведомственного взаимодействия по противодействию преступлениям, совершаемым организованными группами и преступными сообществами (преступными организациями): совместный приказ Генпрокуратуры, МВД, ФСБ, СК, ФСКН, ФТС и ФСИН России от 14.05.2013 № 192/420/279/1071/293; Регламент информационного взаимодействия Банка России, Генпрокуратуры, правоохранительных и иных федеральных государственных органов РФ при выявлении и пресечении незаконных финансовых операций кредитных организаций и их клиентов: совместный приказ Генпрокуратуры, МВД, ФС по ФМ, ФНС, ФСБ, ФСКН, ФТС, СК и Центробанка Росси от 12 марта 2013 № 105/136/ММ-72/117/131/98/447/12/ОД-121.

${ }^{[13]}$ См.: совместный приказ МВД Минобороны, ФСБ, ФСО, СВР, ФСИН, ФСКН, СК России от 27 сентября 2013 № 776/703/509/1820/42/535/398/68.

${ }^{[14]}$ Об утверждении Инструкции о порядке приема, регистрации и разрешения в территориальных органах Министерства внутренних дел Российской Федерации заявлений и сообщений о преступлениях, об административных правонарушениях, о происшествиях : приказ МВД России от 29 августа 2014 № 736.

${ }^{[15]}$ Об утверждении Инструкции о порядке представления результатов оперативно-розыскной деятельности органу дознания, следователю или в суд : приказ МВД России, Минобороны России, ФСБ России, ФСО России, ФТС России, СВР России, ФСИН России, ФСКН России, Следственного Комитета Российской Федерации от 27 сентября 2013 №776/703/509/507/1820/42/535/398/68. 


\section{References}

1] Erkenov S.E. Vzaimodejstvie pravoohranitel'nyh organov stran SNG pri raskrytii i rassledovanii transnacional'nyh prestuplenij : avtoref. dis. ...d-ra. jur. nauk. M., 2000. S. 29: Kucheruk S.A. Taktika i vzaimodejstvie organov sledstvija i doznanija, kak osnova dejatel'nosti pri raskrytii i rassledovanii prestuplenij v osobo slozhnyh uslovijah:avtoref. dis. ...kand. jur. nauk. Krasnodar, 2002. S. 21-22.

[2] Gorjainov K.K., Kvasha Ju.F., Surkov K.V. Federal'nyj Zakon «Ob operativno-rozysknoj dejatel'nosti» : kommentarij. M.: Novyj jurist, 1997; Operativno-rozysknaja dejatel'nost':uchebnik/ pod red. K.K. Gorjainova, V.S. Ovchinskogo, A.Ju. Shumilova. M.: Infra-M: 2002; Osnovy operativnorozysknoj dejatel'nosti: uchebnik / pod red. V.B. RushajloSPb.: Izd-vo Lan', 2002; Shahmatov A.V. Agenturnaja rabota v operativno-rozysknoj dejatel'nosti: monografija/ pod red. V.P. Sal'nikova. SPb.: Sankt-Peterburgskij universitet MVD RF, 2005.

[3] O nekotoryh voprosah organizacii operativno-rozysknoj dejatel'nosti v sisteme MVD Rossii:prikaz MVD RF ot 15.08.2011 № 938; Organizacija sozdanija i raboty sledstvenno-operativnoj gruppy: prikaz MVD RF ot 26.03.2008№ 280; Ob utverzhdenii instrukcii po organizacii operativnosluzhebnoj dejatel'nosti organov vnutrennih del Rossijskoj Federacii pri raskrytii prestuplenij i rassledovanii ugolovnyh del: prikaz MVD RF ot 29.04.2015 № 495.

[4] V ch. 5 i 6 «Mezhdunarodnogo sotrudnichestva v sfere ugolovnogo sudoproizvodstva» $\mathrm{V}$ razdele 18 i 19 UPK RF ne predusmotreno sozdanie sledstvenno-operativnoj gruppy.

[5]Ob utverzhdenii polozhennja ob organizacii mezhvedomstvennogo vzaimodejstvija po protivodejstviju perestuplenijam, sovershaemym organizovannymi gruppami i prestupnymi soobshhestvami (prestupnymi organizacijami): sovmestnyj prikaz Genprokurora RF № 192, MVD RF № 420, FSB RF № 279, SK RF № 15, FS RF po kontrolju za oborotom narkotikov №229, FTS RF № 1071, FSIN RF № 293 ot 14 maja 2013; O merah po protivodejstviju jekstremistskoj dejatel'nosti: prikaz SK RF ot 12.11.2011 № $109 \mathrm{i}$ dr.

[6]Instrukcija ob organizacii raboty postojanno dejstvujushhih sledstvenno-operativnyh grupp po raskrytiju ubijstv: sovmestnyj prikaz Genprokurora RF ot 2 avgusta 1993 № 315-16-93 i MVD RF ot 2.08.1993 № 1/3452; Ob utverzhdenii Polozhenija o sovmestnyh sledstvenno-operativnyh grupp (brigadah) organov prokuratury, vnutrennih del, bezopasnosti i nalogovoj policii dlja presechenija i rassledovanija dejatel'nosti organizovannyh grupp :sovmestnyj prikaz Genprokurora RF № 32 MVD RF № 199, FSB RF № 73, DNP RF № 278 ot 22.05.1995 i dr.

[7] Ob organizacii predvaritel'nogo rassledovanija v SK RF ot 15.01.2011 № 2.

[8] Ob organizacii raboty $\mathrm{v}$ sledstvennom komitete RF po raskrytiju prestuplenij, sovershaemyh v proshlye gody:prikaz SK RF ot 15.01.2011№ 10; Ob ispol'zovanii pensionerov pravoohranitel'nyh organov v kachestve specialistov v sisteme MVD Rossii: prikaz MVD RF ot 29 marta 1993№ 137.

[9] O vzaimodejstvii medicinskih organizacij podvedomstvennyh Ministerstvu zdravoohranenija Respubliki Burjatija, SU SK RF i MVD RF po Respublike Burjatija: sovmestnyj prikaz Minzdrava RB № 4, SU SK RF i RB № 41 i MVD RF po RRB № 845 ot 15.12.2014; Ob organizacii raboty otvetstvennyh ot rukovodstva MVD, UVD OVD i stroevyh podrazdelenij MVD po kontrolju za polnotoj i kachestvom provedenija vsego kompleksa pervonachal'nyh sledstvennooperativnyh i rozysknyh meroprijatij v dezhurnye sutki, koordinacii raboty dezhurnyh narjadov, sil i sredstv OVD i podrazdelenij MVD: prikaz MVD Udmurtskoj Respubliki ot 15.07.2008 № 462; O koordinacionno-metodicheskom sovete po voprosam vzaimodejstvija operativnyh podrazdelenij: sovmestnyj prikaz GU MVD RF po Krasnodarskomu kraju № 283 i UFSKN RF po Krasnodarskomu kraju № 168 ot 28.02.2013; Ob operativno-rozysknoj gruppe MVD po KBR po vyjavleniju i presecheniju kanalov $\mathrm{i}$ istochnikov finansirovanija terroristicheskoj $\mathrm{i}$ jekstremistskoj dejatel'nosti: prikaz MVD po Kabardino-Balkarskoj Respublike ot 6.09.2010 № 510; O postojanno dejstvujushhih 
sledstvenno-operativnyh gruppah: sovmestnyj prikaz Prokuratury № 94, MVD № 34 i Minzdrava Respubliki Bashkortostana № 509-D ot 16.06.2002.

[10] Sozdanie v MVD RF i GU MVD RF po nekotorym sub\#ektam Rossii specializirovannye podrazdelenija (sledstvenno-operativnye gruppy) ili sovmestnye operativnye i rabochie gruppy $\mathrm{v}$ sostave sotrudnikov upravlenija ugolovnogo rozyska, SK RF i Federal'noj sluzhby ispolnenija nakazanija (FSIN). Uchastie sotrudnikov penitenciarnogo vedomstva $\mathrm{v}$ takih rassledovanijah obuslovleno neobhodimost'ju poluchenija informacii ot osuzhdennyh prestupnikov. Novye podrazdelenija uzhe dobilis' pervyh rezul'tatov. Tak, ustanovleny i zaderzhany 16 uchastnikov bandy, sovershivshih za 10 let na territorii Primorskogo kraja 18 ubijstv. Krome togo, zaderzhany vosem' uchastnikov organizovannogo prestupnogo soobshhestva, dejstvujushhego v Privolzhskom federal'nom okruge. Chleny jetoj gruppirovki sovershili s 2002 po 2006 god 19 ubijstv, prichem ih zhertvoj stal lider sojuza predprinimatelej Mordovii Fedor Kataev. Eshhe odin primer raskrytogo rezonansnogo prestuplenija - dvojnoe ubijstvo prezidenta i ispolnitel'nogo direktora Moskovskoj oblastnoj notarial'noj palaty Chelysheva i Petrinskogo, sovershennoe v 2008 godu. Vsego za 11 mesjacev 2010 g., bylo raskryto 762 «staryh» prestuplenija. (Sm.: Informacija na sajte: http: //-news/2011/01/14/3993123v_mvd_rf_vpervye_formiruyut_specpodra...12.06.2015).

[11] Sm.: Prikaz MVD SSSR ot 30.04.1990 № 186; O sozdanii sledstvenno-operativnoj gruppy MVD RF dlja koordinacii dejatel'nosti sluzhb MVD i organov vnutrennih del po raskrytiju i rassledovaniju pozharov i podzhogov :prikaz MVD RF ot 12.05.1993 № 224; Ob organizacii vzaimodejstvija organov GPN FPS GPS RF i organov vnutrennih del RF v ispol'zovanii jekspertnokriminalisticheskih sredstv i metodov v raskrytii i rassledovanii prestuplenij : sovmestnyj prikaz Ministerstva RF po delam grazhdanskoj oborony, chrezvychajnym situacijam i likvidacii stihijnyh bedstvij № 549 i MVD RF № 868 ot 17 sentjabrja 2012.

[12] Ob utverzhdenii Polozhenija ob operativno-rozysknoj gruppe (specotdela) MVD Kabardino-Balkarskoj Respubliki po vyjavleniju i presecheniju kanalov i istochnikov finansirovanija terroristicheskoj i jekstremistkoj dejatel'nosti: prikaz MVD po KBR ot 06.09.2010 № 510; Instrukcija po organizacii vzaimodejstvija MVD RF, Minoborony RF, FSB, SVR i FS po finansovomu monitoru po presecheniju finansirovanija iz zarubezhnyh istochnikov nezakonnyh vooruzhennyh formirovanij dejstvujushhih v Severo-Kavkazskom regione Rossijskoj Federacii: sovmestnyj prikaz MVD, Minoborony, FSB, SVR i FS po FM Rossii ot 14 maja 2007 № 426/183/117/43/106; Polozhenie ob organizacii mezhvedomstvennogo vzaimodejstvija po protivodejstviju prestuplenijam, sovershaemym organizovannymi gruppami i prestupnymi soobshhestvami (prestupnymi organizacijami): sovmestnyj prikaz Genprokuratury, MVD, FSB, SK, FSKN, FTS i FSIN Rossii ot 14.05.2013 № 192/420/279/1071/293; Reglament informacionnogo vzaimodejstvija Banka Rossii, Genprokuratury, pravoohranitel'nyh i inyh federal'nyh gosudarstvennyh organov RF pri vyjavlenii i presechenii nezakonnyh finansovyh operacij kreditnyh organizacij i ih klientov: sovmestnyj prikaz Genprokuratury, MVD, FS po FM, FNS, FSB, FSKN, FTS, SK i Centrobanka Rossi ot 12 marta 2013 № 105/136/MM7-2/117/131/98/447/12/OD-121.

[13] Sm.: sovmestnyj prikaz MVD Minoborony, FSB, FSO, SVR, FSIN, FSKN, SK Rossii ot 27 sentjabrja 2013 № 776/703/509/1820/42/535/398/68.

[14] Ob utverzhdenii Instrukcii o porjadke priema, registracii i razreshenija v territorial'nyh organah Ministerstva vnutrennih del Rossijskoj Federacii zajavlenij i soobshhenij o prestuplenijah, ob administrativnyh pravonarushenijah, o proisshestvijah : prikaz MVD Rossii ot 29 avgusta 2014 № 736.

[15] Ob utverzhdenii Instrukcii o porjadke predstavlenija rezul'tatov operativno-rozysknoj dejatel'nosti organu doznanija, sledovatelju ili v sud : prikaz MVD Rossii, Minoborony Rossii, FSB Rossii, FSO Rossii, FTS Rossii, SVR Rossii, FSIN Rossii, FSKN Rossii, Sledstvennogo Komiteta Rossijskoj Federacii ot 27 sentjabrja 2013 №776/703/509/507/1820/42/535/398/68. 